\title{
The Effects of Heat Treatment on the Tensile Properties of Camshaft made of GGG70 Series Spherical Graphite Cast Iron
}

\author{
B. KARACA ${ }^{a, *}$ AND M. ŞİMŞiR ${ }^{b}$ \\ ${ }^{a}$ ESTAŞ Eksantrik San. ve Tic. A.Ş., 58060 Sivas, Turkey, \\ ${ }^{b}$ Cumhuriyet University, Department of Metallurgy and Materials Eng., 58100 Sivas, Turkey
}

\begin{abstract}
The aim of this study is to investigate the effects of austempering and induction hardening on the tensile properties of GGG70 ductile cast iron for camshaft production. For this purpose, camshafts have been produced by sand mould casting method. For nodulizing process, $\mathrm{Fe}-\mathrm{Si}-\mathrm{Mg}$ alloy has been used and $\mathrm{Fe}-\mathrm{Si}-\mathrm{Ba}-\mathrm{Ca}-\mathrm{Al}$ alloy has been for inoculation process. The casting has been done between $1420-1440^{\circ} \mathrm{C}$ and the pouring time was in between 11-13 s. The casted camshafts have been austenitized at two different temperatures and time under controlled furnace atmosphere. The austenitized camshafts have been quenched into the molten salt bath at $320^{\circ} \mathrm{C}$ temperature and held $90 \mathrm{~min}$ and then cooled in air. By this way, austempering heat treatment has been applied. After that, surface hardening process was conducted by induction hardening machine with medium frequency. Microstructures of camshafts have been examined by optical and mechanical tests (hardness and tensile tests) have been performed. The fracture surfaces of tensile specimens were examined by SEM analysis. Results show that austempering heat treatment increases the tensile strength of camshaft as-cast condition. Tensile strength of the cam shaft increases with increasing austenitizing temperature, time and induction hardening. The highest tensile strength $1285 \mathrm{MPa}$, has been obtained from the induction hardened camshaft austenitized at $900^{\circ} \mathrm{C}$ and $90 \mathrm{~min}$ time.
\end{abstract}

DOI: 10.12693/APhysPolA.135.811

PACS/topics: casting, austempering, induction hardening, tensile properties, SEM

\section{Introduction}

The production of camshafts used in engines is carried out with the casting and machining techniques. Today, camshafts are produced from gray, nodular graphite cast iron, because of many advantages, or by machining of steel [1].

Nodular cast iron (ductile iron) is more convenient and better in terms of production costs compared to production of machining methods. At the same time, it is $10 \%$ lighter than steels. Austempered ductile iron (ADI), as compared with steel, has lower material and production cost, lower density, better process ability and higher vibration damping ability. As a result of the superior properties, ADI has growing popularity in many fields and became the subject of this study [2].

In ADI, ausferrite (austenite + ferrite) matrix structure is formed in austempering process that differs from bainitic structure being formed in steels. Therefore, it has different mechanical properties. When the literature is reviewed, it should be noted that researches on this subject have been going on $[3,4]$.

Spherical graphite cast iron that is hardened by induction are frequently used in structural elements where wear, fatigue and tensile strength should be good, such as camshafts, which are important tasks in motor vehicles in the automotive industry $[5,6]$.

*corresponding author; e-mail: bahadir.karaca@estas.com.tr
Different structures are formed in ductile graphite cast iron by surface hardening with induction process according to steel materials. Thus, it has different mechanical properties and studies are going about this topic when we see the on literature $[7,8]$.

The aim of this study is to investigate the effects of austempering and induction hardening on microstructure and tensile properties of small sections of camshaft.

\section{Materials and equipments}

Sand mould for the camshaft casting was prepared. Melting process was conducted in induction furnaces. The chemical composition was analyzed by spectrometer and Atas termal analysis equipment. Table I shows the chemical composition of cast iron used in camshaft production.

Nodulizing process was done in the treatment crucible at the temperature between $1550-1570^{\circ} \mathrm{C}$ and $\mathrm{Fe}-\mathrm{Si}-\mathrm{Mg}$ alloy was used for nodulizing treatment. While liquid metal was poured into casting crucible, $\mathrm{Fe}-\mathrm{Si}-\mathrm{Ba}-\mathrm{Ca}-\mathrm{Al}$ alloy was added for inoculation process. Casting process was completed between 11-13 s and at the temperature of about $1415^{\circ} \mathrm{C}$ determined by laser type thermocouple. Both camshaft and tensile samples ( $\mathrm{Y}$ blocks) were casted by sand mold casting method.

Sand remaining on the camshafts and Y blocks surfaces has been cleaned by sand blasting device. The runners and risers of camshafts and $\mathrm{Y}$ blocks were separated by cutting and their surfaces were ground on CNC machines. Tensile test samples were produced from Y blocks according to ASTM A597 standard (Fig. 1). 
TABLE I

Chemical composition [\%] of the casted camshaft.

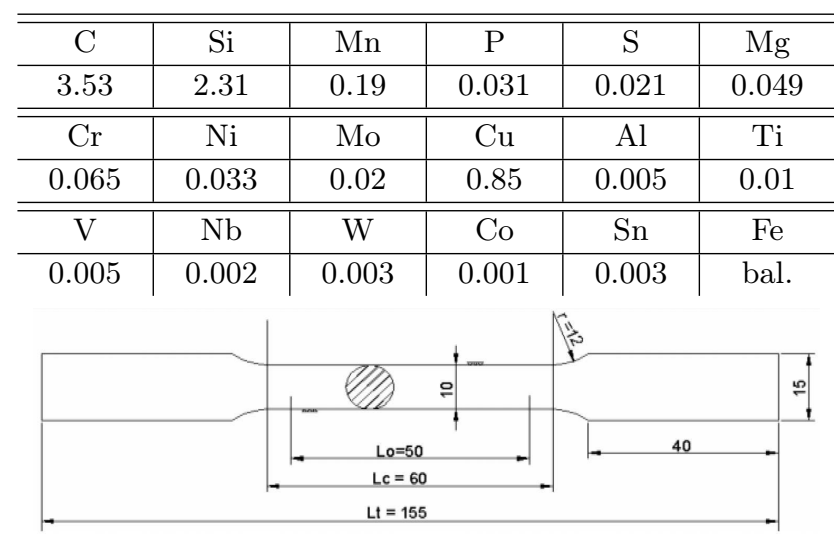

Fig. 1. ASTM A597 standard tensile sample 2D technical drawings.

In the austempering heat treatment, cabin type electric furnace was used. It attains the temperature up to $1100^{\circ} \mathrm{C}$ and assures atmosphere and temperature control. After the camshafts were austenitized at 800 and $900{ }^{\circ} \mathrm{C}$, for 60 and 90 minutes, camshafts austempered rapidly in salt bath $\left(50 \% \mathrm{KNO}_{3}+50 \% \mathrm{NaNO}_{3}\right)$ at $320^{\circ} \mathrm{C}$ for 90 min. After that, camshafts were air cooled to room temperature.

When surface hardening heat treatment was conducted with medium frequency induction machine, it was obtained temperature control by thermal cameras for the samples of camshafts. Surface microstructure was changed by induction heating between $4-6$ times.

Heat treated camshafts samples were made ready for microstructure investigation by standard metallographic methods (mounting, grinding, polishing) and then etching process was applied by using $2 \%$ nital solution. The microstructure of the camshaft was examined under a Nikon MA200 optical microscopy and analyzed by Clemex Vision Lite image analysis software. The nodularity rate, nodule size and number, graphite volume percentage, ferrite and pearlite rate were measured. graphite, ferrite and pearlite were measured. SEM images were used to characterize the fracture surfaces in the tensile test results.

Hardness of core sections of camshafts as casted and austempered were measured applying $750 \mathrm{kgf}$ load in terms of the Brinell hardness by Instron Wolpert hardness device. After induction hardening process of the surface, hardness of each cam was measured applying $150 \mathrm{kgf}$ load according to Rockwell method by Instron Wolpert hardness device. Hardness test was performed five times at different sections.

Tensile test machine, called ALSA, with 20 tons load was used for tension test. Tensile strength, yield strength and the elongation were determined. Tension test were conducted three times and average values of tensile properties were given and then the fracture surfaces of each sample were depicted by SEM.

\section{Results and discussion}

The results of the image analysis obtained by Clemex Vision Lite program are given in Table II. As can be seen in the table: nodularity percentage, nodules number and size, graphite, ferrite and pearlite volume ratio values are close to that in standard GGG70 cast iron. The data confirm, that the method implemented to the camshaft production is correct and reliable.

Microstructure analysis results

TABLE II

\begin{tabular}{c|c|c|c|c|c}
\hline \hline $\begin{array}{c}\text { Nodularity } \\
{[\%]}\end{array}$ & $\begin{array}{c}\text { Nodule } \\
\text { count } \\
{\left[\mathrm{mm}^{2}\right]}\end{array}$ & $\begin{array}{c}\text { Size } \\
\text { of nodule } \\
{[\mu \mathrm{m}]}\end{array}$ & $\begin{array}{c}\text { Graphite } \\
\text { volume } \\
{[\%]}\end{array}$ & $\begin{array}{c}\text { Ferrite } \\
\text { volume } \\
{[\%]}\end{array}$ & $\begin{array}{c}\text { Perlite } \\
\text { volume } \\
{[\%]}\end{array}$ \\
\hline 92 & 340 & 28.7 & 15.61 & 22.71 & 61.68
\end{tabular}

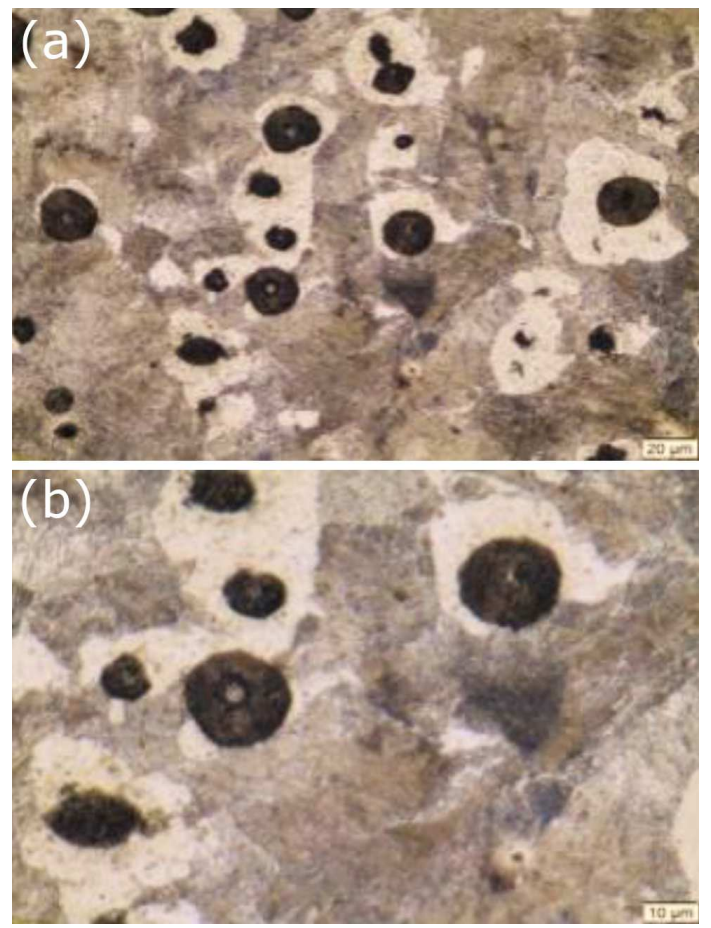

Fig. 2. The microstructure of the cast camshaft; (a) $100 \times$, (b) $200 \times$.

Camshaft microstructure is given in Fig. 2a, b. The microstructure is typical for graphite cast iron casts structure. The ductile graphite nodules contain ferriteconverted particles, which are carbonized around them, and a perlitic matrix outside the nodules (Fig. 2a, b).

After the austenitizing process, the samples of the camshaft for the microstructure analisys were retrieved and austempered at $320^{\circ} \mathrm{C}$ for $90 \mathrm{~min}$. The results are shown in Fig. 3. The ductile graphite nodules are surrounded by bainitic ausferrite formed during austempering. Some palpable dark brown areas resemble sorbitos (Fig. 3a, b). The etched microstructure images reveal the austempering effect. The matrix also exhibits a brown shade bainitic matrix structure with austenite-ferrite grains encircled in light gray (Fig. 3c, d). 

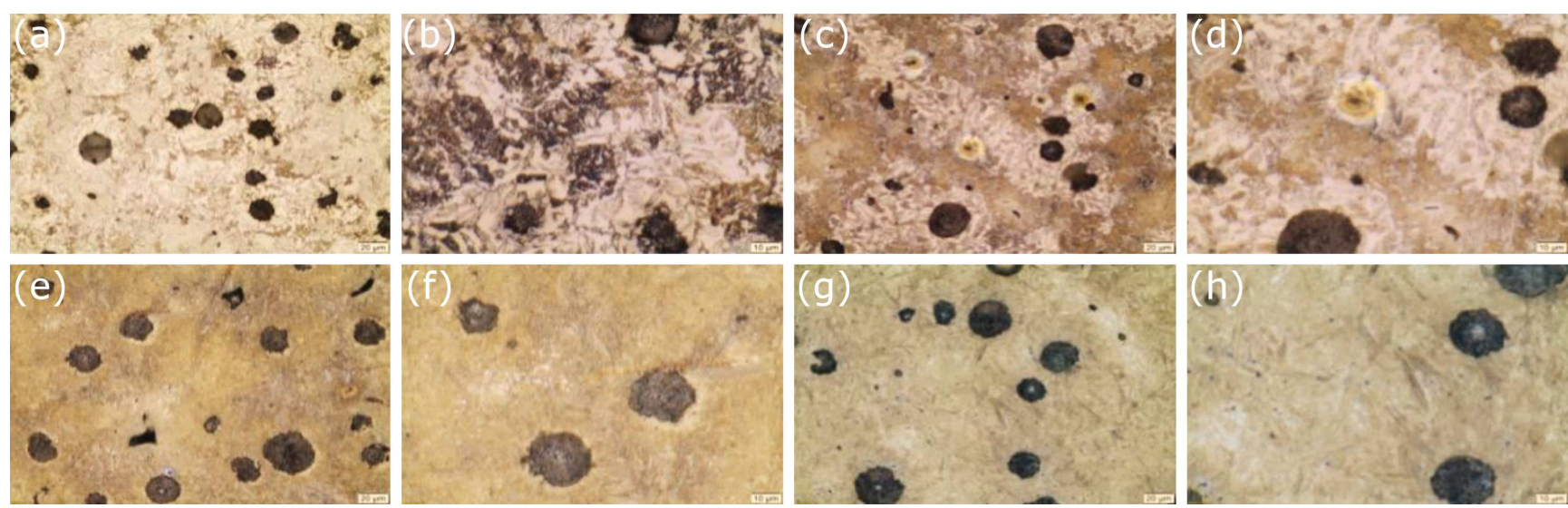

Fig. 3. Microstructures of austempered camshaft; austenitized at $800^{\circ} \mathrm{C}, 60 \mathrm{~min}$ (a) $100 \times$, (b) $200 \times$; austenitized at $800^{\circ} \mathrm{C}, 90 \mathrm{~min}(\mathrm{c}) 100 \times$, (d) $200 \times$; austenitized at $900^{\circ} \mathrm{C}, 60 \mathrm{~min}(\mathrm{e}) 100 \times$, (f) $200 \times$ and austenitized at $900{ }^{\circ} \mathrm{C}, 90 \mathrm{~min}$ (g) $100 \times$, (h) $200 \times$.
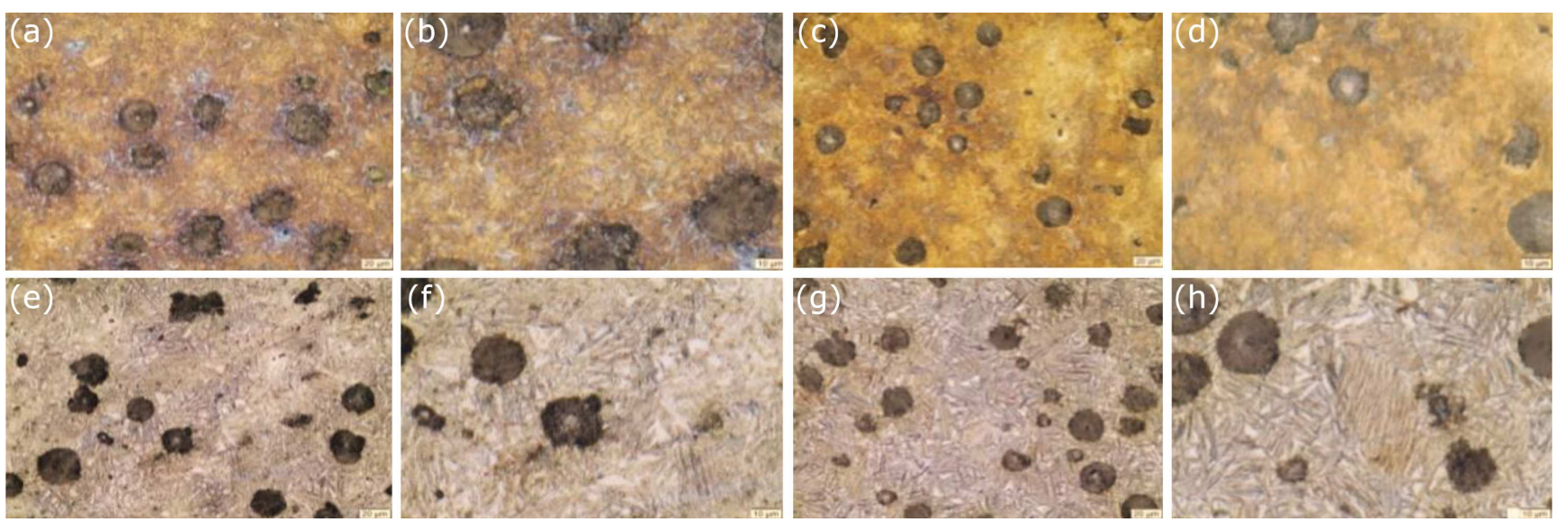

Fig. 4. Surface microstructure of austempered and induction hardened camshaft with austenitizing and induction at $800^{\circ} \mathrm{C}, 60 \mathrm{~min}(\mathrm{a}) 100 \times$, (b) $200 \times$; at $800^{\circ} \mathrm{C}, 90 \mathrm{~min}$, (c) $100 \times$, (d) $200 \times$; at $900{ }^{\circ} \mathrm{C}, 60 \mathrm{~min}$, (e) $100 \times$, (f) $200 \times$ at $\left.900^{\circ} \mathrm{C}, 90 \mathrm{~min},(\mathrm{~g}) 100 \times, \mathrm{h}\right) 200 \times$.

The matrix has been transformed into ausferrite structure in the austempering process. The structure consisting of needle-like ferrite grains contain the precipitates and a mixture of austenite grains brighter in contrast and higher in carbon dissolution (Fig. 3e-h). It is observed that when austenitizing time has increased, austenite phase rate is increased in the structure also. With increasing austenitizing temperature, it has been obtained a more homogeneous ausferrit. With increasing austenitizing temperature and time, austenite phase was found to be more homogeneous.

Figure 4 shows the microstructure of the austenitized hardened by induction. It might be said, that the formation of a mixed matrix containing fine graphite nodules, fine martensitic and needle ferrites as well as form the etched microstructure images, and this matrix structure is obtained due to the induction hardening (Fig. 4ad). The needle ferrite grains are seen as gray contrasted discs. Beride them, the matrix is mainly fine martensitic (Fig. $4 \mathrm{e}-\mathrm{h}$ ).
The core of the camshaft cools slower than its surface, and therefore it is softer, as measured with the Brinell hardness. The results of the hardness measurements of the cam cross section is shown in Fig. 5. Three results of hardness at each point in the the core and on the surface, depending on the applied heat treatment, is given in Fig. 5. The results show that the core of austempered camshaft (Fig. 5b, d, f, h) is $23 \%$ harder than that of casted camshaft (Fig. 5a). The core hardness of camshaft with austempered + induction hardened (Fig. 5c, e, g, k) is $35 \%$ higher than that of as-casted camshaft (Fig. 5a). This is due to higher cooling rate of core of the austempered and induction hardened camshafts than that of camshaft in as-cast condition. When the surface hardness values are compared, it is seen that the microstructure of the surface was formed differently. With induction hardening heat treatment it is martensitic microstructure, was obtained on the surface of the camshaft; in austempered camshaft it is ausferritic; in the as-cast camshaft it is perlitic-ferritic. 

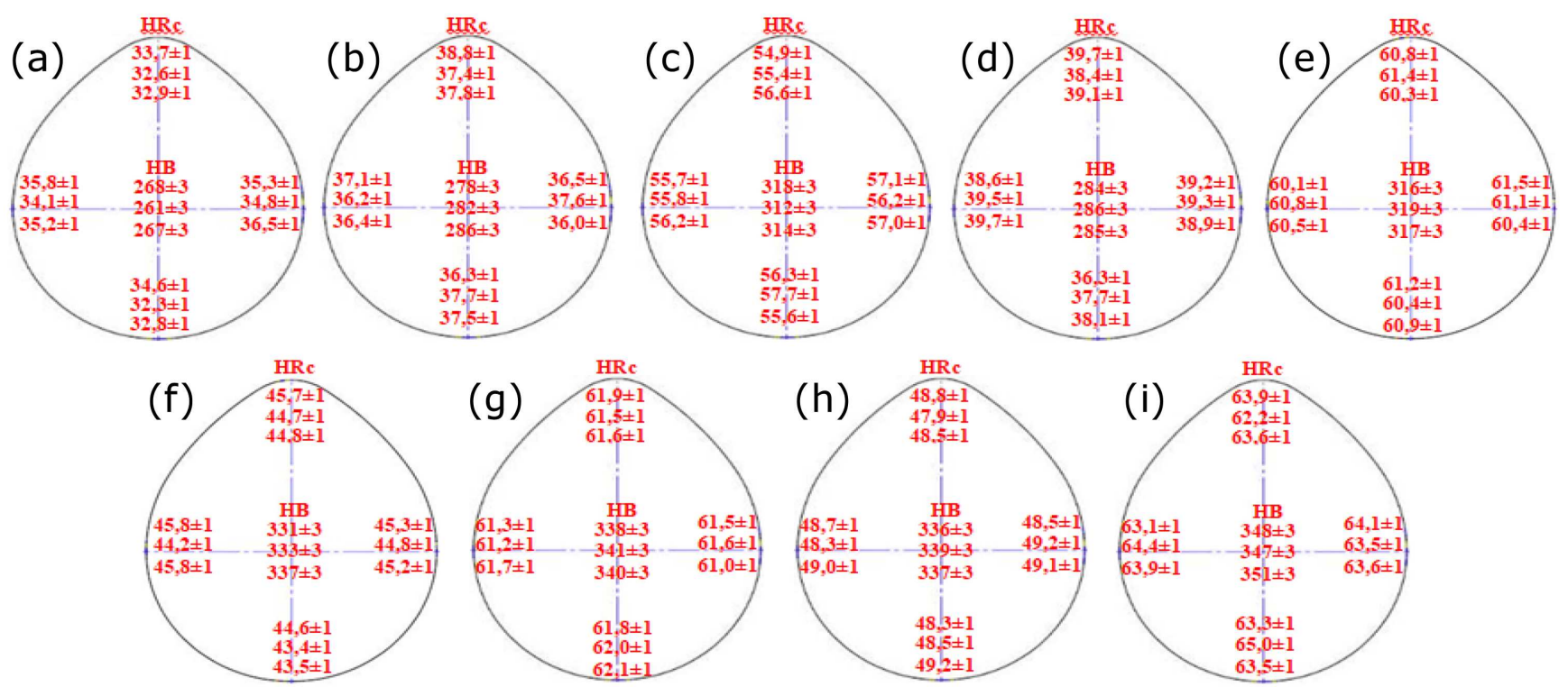

Fig. 5. The results of hardness camshaft at; (a) casting, (b) $800^{\circ} \mathrm{C}, 60 \mathrm{~min}$ austenitized, (c) $800^{\circ} \mathrm{C}$, 60 min austenitized and induciton hardened, (d) $800^{\circ} \mathrm{C}, 90$ min austenitized, (e) $800^{\circ} \mathrm{C}, 90 \mathrm{~min}$ austenitized and induciton hardened, (f) $900{ }^{\circ} \mathrm{C}, 60 \mathrm{~min}$ austenitized (g) $900{ }^{\circ} \mathrm{C}, 60 \mathrm{~min}$ austenitized and induciton hardened, (h) $900{ }^{\circ} \mathrm{C}, 90 \mathrm{~min}$ austenitized, (i) $900^{\circ} \mathrm{C}, 90 \mathrm{~min}$ austenitized and induciton hardened.

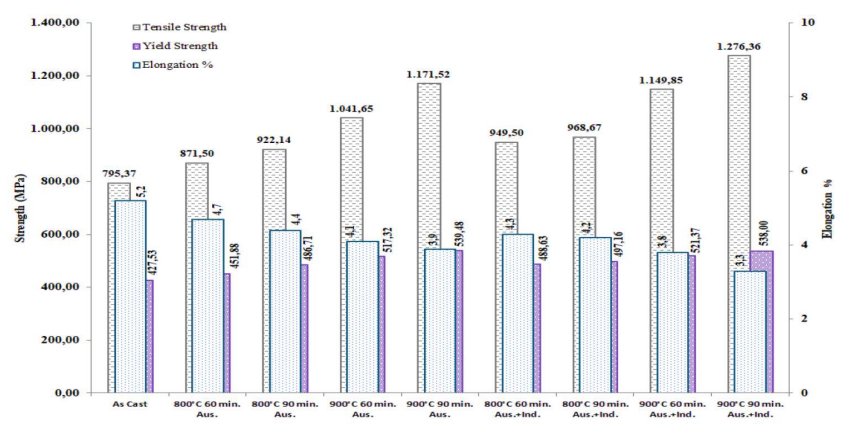

Fig. 6. Tensile test results.

Tensile tests were conducted three times for each sample and average values of tensile properties were calculated and submitted. Tensile test results were given in Fig. 6. As it can be seen, when austenitizing temperature and time are increased, the tensile and yield strengths increases but elongation decreases. The highest tensile and yield strength values were obtained for the camshaft austenitized at $900^{\circ} \mathrm{C}$ and $90 \mathrm{~min}$. The increase in tensile strength and austempering grade is linked with thin ausferritic structure to perlitic structure.

SEM imases serve to characterize the casting fracture surface. Figure $7 \mathrm{a}-\mathrm{d}$ shows the fracture surface after tensile test of as-cast sample. Generally, the fracture surface displays brittle characteristic (Fig. 7a, b). The fracture reflects the ferritic-pearlitic structure of the matrix. Facet sections on the fracture surface contain ferritic areas and lamel looking sections contains pearlitic areas (Fig. 7c, d). Similar SEM images of the fracture is obtained for the other structures.
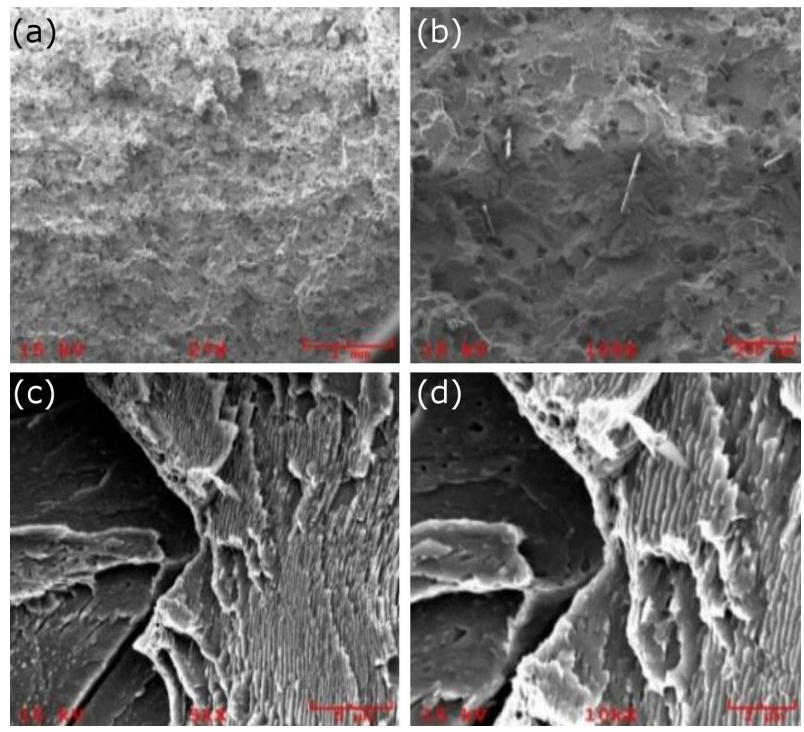

Fig. 7. The SEM images of samples taken from the surface rupture under casting conditions; (a) general view, (b) a detail from the middle part, (c) high magnification matrix details, (d) high magnification details.

Fracture surface of the austenitized sample tensile test at $800^{\circ} \mathrm{C}$ for 60 minutes is presented in Fig. 8. Homogeneous distribution of the graphite and no segregation tendencies in the matrix are revealed. The fracture fits generally to a brittle characteristic. Diminution of the section is quite, because because the fault lies only along the cleavage plane of the fracture surface and covers usually about $1.2 \%$ of the tested sample (in Fig. $8 \mathrm{~b}$, the region inside the red circle and the like). The breakage in 

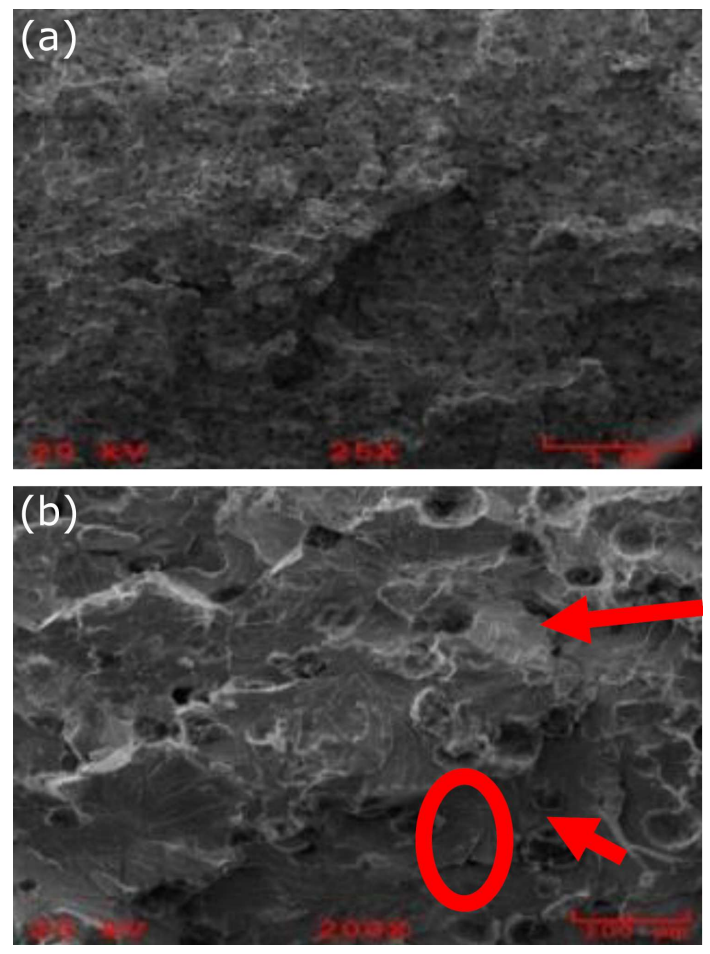

Fig. 8. The images of samples taken from the surface rupture under austempering conditions at $800{ }^{\circ} \mathrm{C}$ for 60 minutes; (a) general view of lower magnifying, (b) detail view.
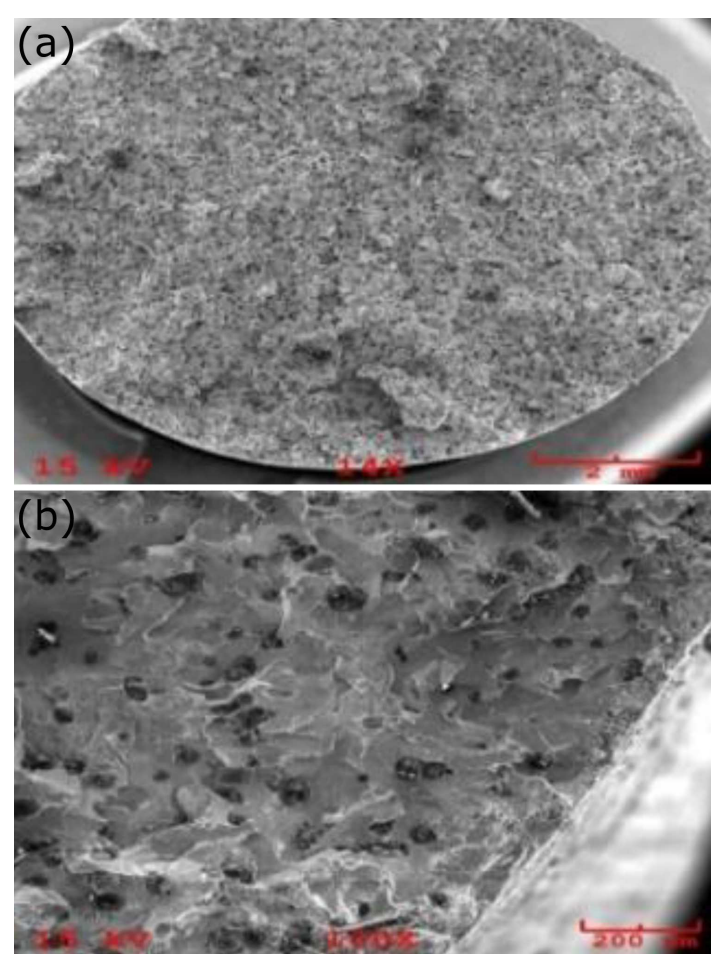

Fig. 9. The images of samples taken from the surface rupture under austempering and induction hardening conditions at $800^{\circ} \mathrm{C}$ for 60 minutes; (a) general view of lower magnifying, (b) detail view.
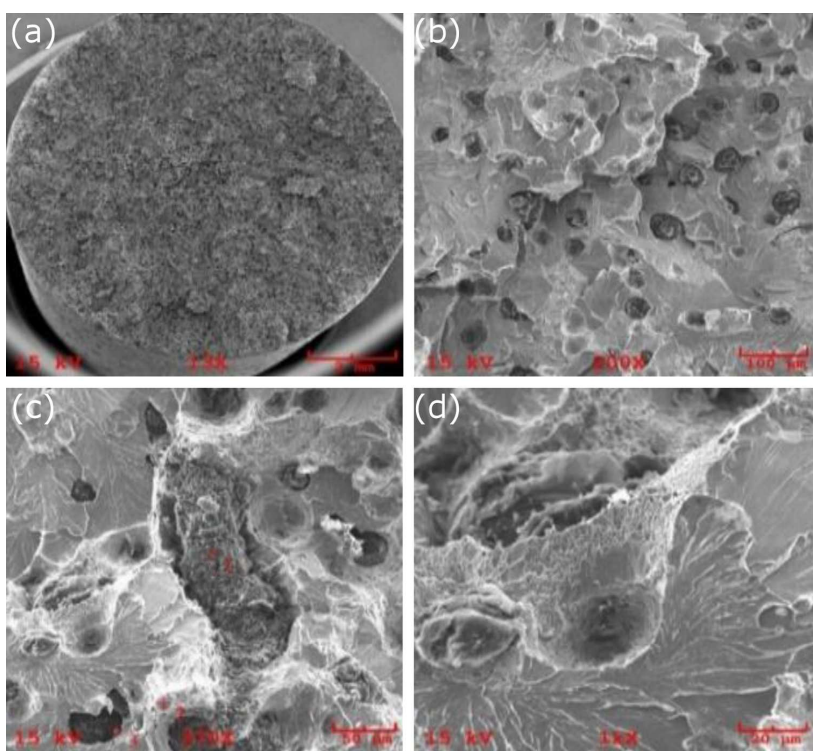

Fig. 10. Review of samples rupture surface under condition of austempering at $800^{\circ} \mathrm{C}$ for 90 minutes; (a) general view of lower magnifying, (b) detail view, (c) the detail view of the fracture surface with different secondary phases, (d) the plastic deformation zone formed along the sides of the secondary phase.

the material along cleavage planes is ductile fracture. Beside fracture structure often exhibit fracture particul that is one specific characteristic of austempered cast iron, it also show characteristics of grain boundary fracture.

Fracture surface of the austenitized at $800{ }^{\circ} \mathrm{C}$ for 60 minutes and induction hardened tensile test sample is shown in Fig. 9. The general view (Fig. 9a) reveals, that the distribution of graphite is homogeneous. The section narrowing is at the level of $3.6 \%$. The higher magnification SEM image shows that intragranular fracture occurs in the material (Fig. 9b). In this material, surface and inter-center investigations suggested that the surface treatment does not change the general fracture behavior.

Fracture surface of the tensile test sample austenitized at $800{ }^{\circ} \mathrm{C}$ for 90 minutes are shown in Fig. 10. General view particularly shows that there is a high nodular graphite density in the central region of the sample. Such a heterogeneity of the structure is considered as a disadvantage in terms of mechanical properties. Intergranular fracture was observed on the fracture surface (Fig. 10c). Cavities are formed by microvoid coalescences mechanism that reflects ductile fracture characteristics in the areas (Fig. 10d). Occurrence of these kind of fracture reveals presence of tough section and high ability of plastic deformation of the material.

Fracture surface of the austenitized at $800{ }^{\circ} \mathrm{C}$ for 90 minutes and induction hardened tensile test sample is presented in Fig. 11. The general appearance of the fractured surface shows the graphite segregation in the center (Fig. 11a). The section narrowing is around $2.5 \%$ and the material is cracked brittly. Advanced fracture at intergranular areas were observed on the fracture planes over 
typical cleavage planes detected on the surfaces of other materials (Fig. 11b). Two different fracture structures are observed on the fracture surface as shown in Figure 11c. In the upper right corner of the SEM image, brittle fracture occurs in the area marked by the ring, while fracture dissociation in the area within the red square is more ductile. In Fig. 11d, the higher magnification SEM image of the square-marked area shows more details of the areas that have higher plastic deformation capability.
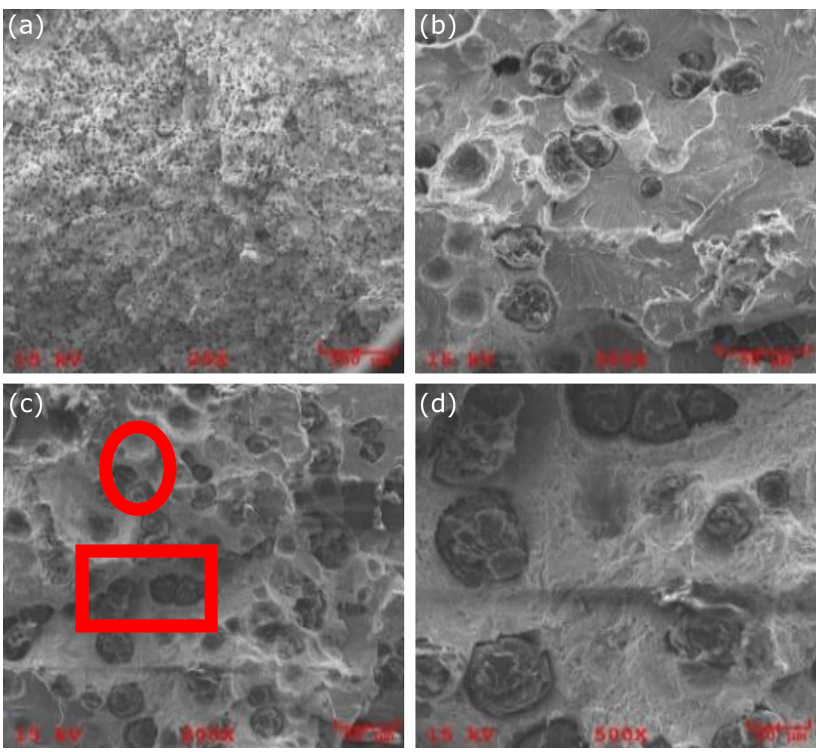

Fig. 11. The images of samples taken from the surface rupture under austempering and induction hardening conditions at $800^{\circ} \mathrm{C}$ for 90 minutes; (a) general view, (b) a detail from the middle part, (c) a fracture appearance displaying two different fracture characteristics, (d) a detail view of the plastic deformation areas on the periphery of a graphite housing.
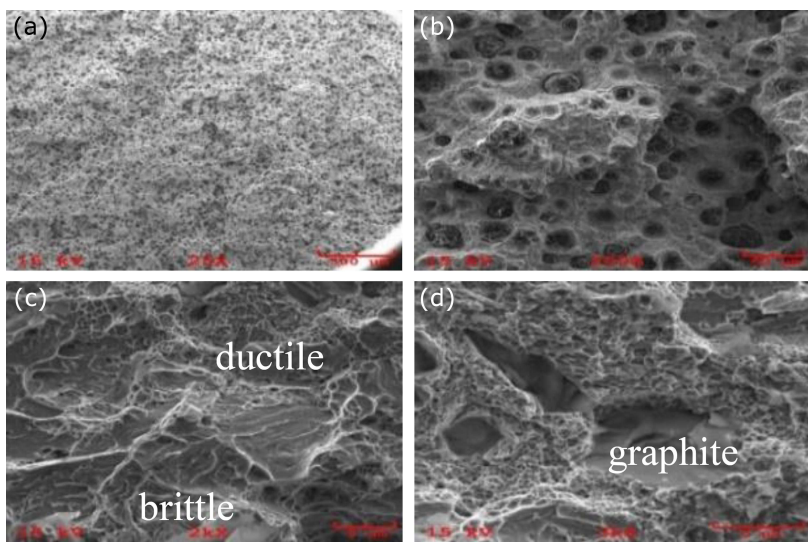

Fig. 12. The images of samples taken from the surface rupture under austempering conditions at $900^{\circ} \mathrm{C}$ for 60 minutes; (a) view of an internal structure exhibiting two different refractive characteristics, (b) brittlelike fracture in a detail view, $(\mathrm{c}, \mathrm{d})$ different zones in a detail view.
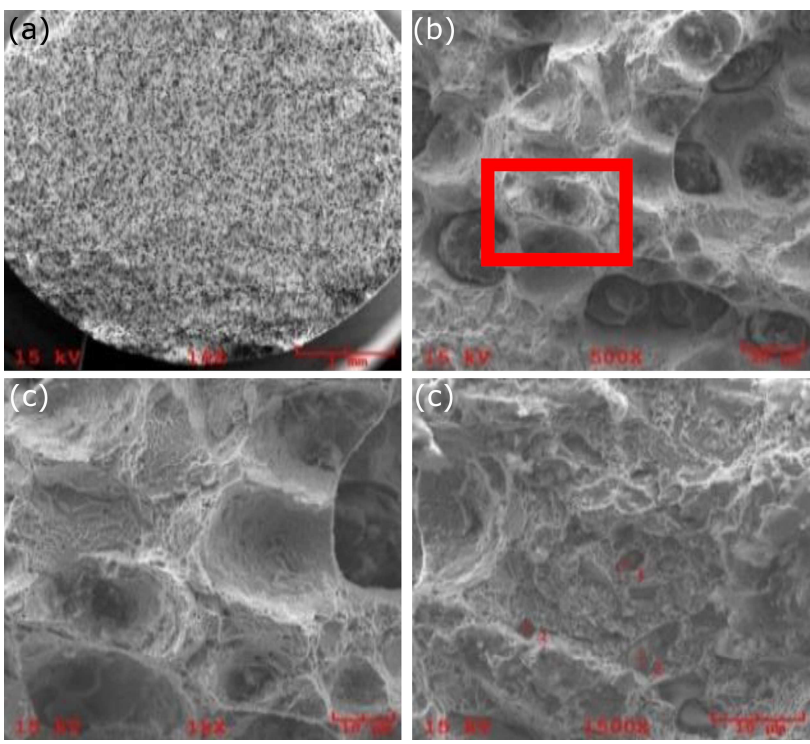

Fig. 13. The images of samples taken from the surface rupture under austempering and induction hardening conditions at $900{ }^{\circ} \mathrm{C}$ for 60 minutes; (a) general view, (b) a detail from the middle part, (c) detail view, (d) detail view from near to the surface; oxide particles take place in the ferritic matrix.

Figure 12 shows the surface of the austenitized at $90{ }^{\circ} \mathrm{C}$ for $60 \mathrm{~min}$ tensile test sample. At high tempareture, microvoid coalescence mechanism is observed, so ductile fracture in the austenitized sample can be seen in the wide area. The graphite distribution is homogene, fracture surface has the mode of ductile fracture (Fig. 12a, b). The presence of the plastic flow can also be explained by the presence of large areas in the form of pits (Fig. 12c, d).

Fracture surface of the austenitized at $900{ }^{\circ} \mathrm{C}$ for $60 \mathrm{~min}$ and induction hardened tensile test sample is presented in Fig. 13. In general fracture surface shows no graphite segregation (Fig. 13a). The fracture surface contains secondary phase particles as well as areas exhibiting mixed fracture including ductile and brittle fracture (Figs. 13 b-d). The analyzes made at different points (regions 1 and 2 in Fig. 13d) show that the oxide-based particles are $\mathrm{MgO}$ based. Oxidic residues are also phase particles that promote fracture, as graphite does.

Fracture surface of austenitized at $900^{\circ} \mathrm{C}$ for $90 \mathrm{~min}$ sample with is presented in Fig. 14. The fracture exhibits mixed rupture separation, as fracture surface can be divided in two types; ductile and brittle fracture (Fig. 14a, b). Fracture surface contain significant cleavage planes as well as the form of pits (Fig. 14c, d).

Fracture surface of the austenitized at $900^{\circ} \mathrm{C}$ for $90 \mathrm{~min}$ and induction hardened tensile test sample is presented in Fig. 15. In this material, other fracture characteristics was found. In low magnification images (Fig. 15a, b), this difference is not very obvious but it is visible at high magnification (Fig. 15c, d). The brittle fracture occurrs in similar manner to the fracture mode of the hardened steels, ductile fracture is not alike. 

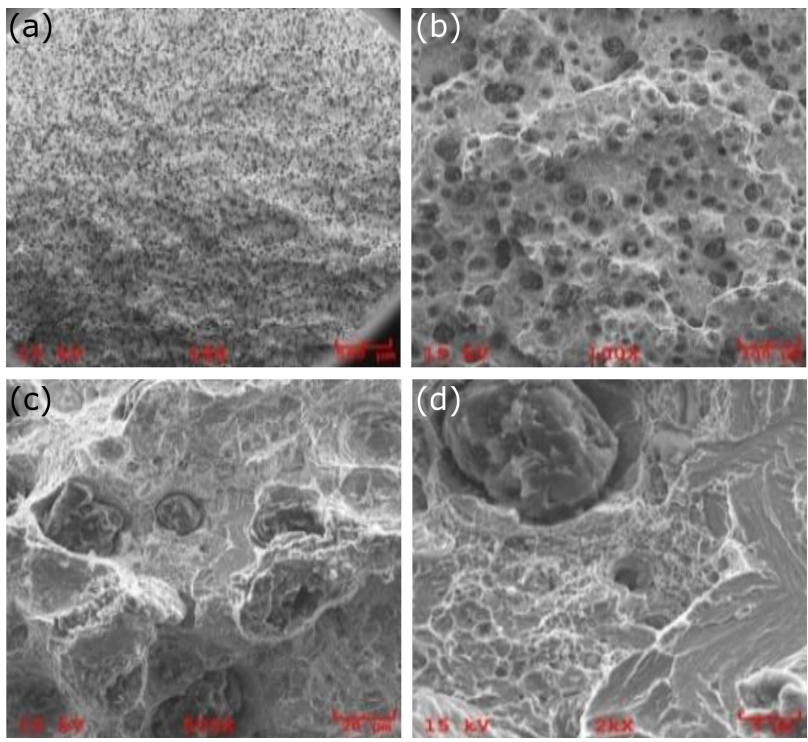

Fig. 14. The images of samples taken from the surface rupture under austempering conditions at $900^{\circ} \mathrm{C}$ for 90 minutes; (a) general view of lower magnifying, (b) detail view, (c) a detail view through sample, (d) a detail from a view; fracture surface contains ductile and brittle fracture characteristics.
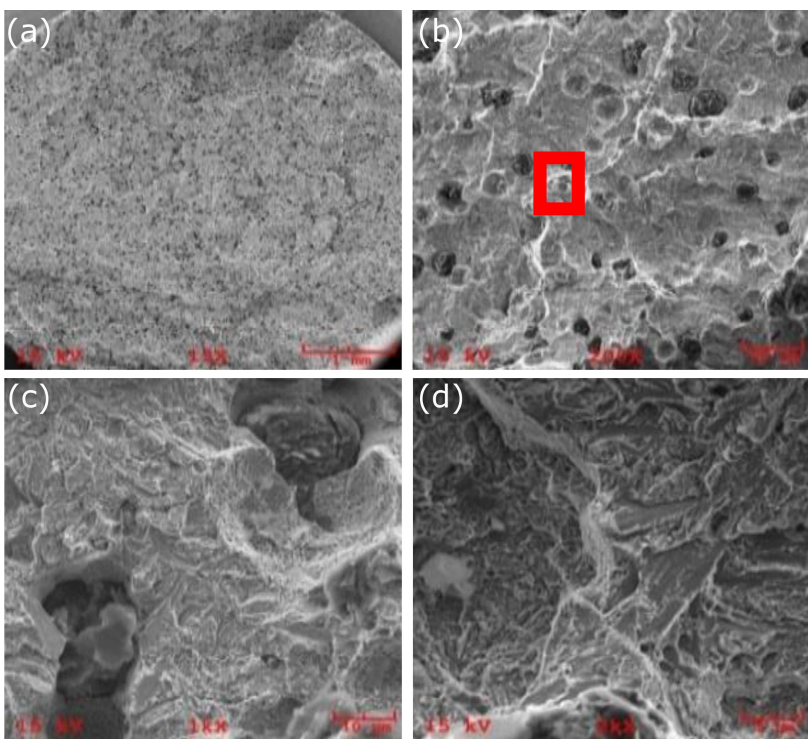

Fig. 15. The images of samples taken from the surface rupture under austempering and induction hardening conditions at $900{ }^{\circ} \mathrm{C}$ for 90 minutes; (a) general view, (b) a detail from the middle part, (c) detail view, (d) detail view that shows the fracture character of the matrix to the surface.

It can be concluded that as austenitizing temperature and time are increased, fracture mechanism changes from brittle to ductile type fracture. It is found, that the grains of the austenite grow with increase of austenitizing temperature and time. Amount of ausferrite phase increases under the same condition, and carbon diffuses easily from ferrite phase into austenite phase.

\section{Conclusions}

In this study, the effects of austempering and austempering + induction hardening heat treatments on the tensile strength and microstructure of camshaft made of ductile cast iron were investigated. The following results were obtained;

1. Microstructure of as-cast samples reveals graphite nodules and ferritic-pearlitic matrix structure, austempered samples contains ausferrite (austenite + ferrite) microstructure. The microstructure of the core of austempered + induction hardened camshaft contains graphite nodules and holds on its ausferrit microstructure. The microstructure of its surface consists of nodule graphite, fine martensite, some untransformed austenite and some needle ferrite.

2. Austempering process applied on GGG70 class nodular cast iron augments the core hardness value from $261 \mathrm{HB}$ to $339 \mathrm{HB}$, and surface hardness value from $32.3 \mathrm{HRc}$ to $49.2 \mathrm{HRc}$. After induction hardened heat treatment, the core hardness value increases to $365 \mathrm{HB}$, and surface hardness to 65.0 HRc.

3. The austempered and induction hardened cast iron from the camshaft has $60-65 \%$ higher tensile strength than the as-cast one. The maximum tensile strength was obtained from the camshaft austenitized at $900{ }^{\circ} \mathrm{C}$ for $90 \mathrm{~min}$ and induction hardened. Similar results were obtained for yield strength. However, the elongation is decreased by austempering heat treatment.

4. Tensile properties are augmented by increasing of the austenitizing and induction hardening temperature and the time, but simultaneosly it decreases the elongation.

5. Fracture mechanisms were determined on the base of SEM images. It is concluded that ductile and brittle fracture modes can be detected on all fracture surfaces. The increase of austenitizing temperature and time unveils ductile fractures in wide region of the fracture surface. This is due to the growing presence of ausferritic phase in the microstructure. After the surface hardening process, the contribution of the brittle fracture areas grows, and the image displays more disintegrating intergranular fractures.

\section{References}

[1] J.L. Doong, C.S. Chen, Fatigue Frac. Engng. Mater. Struct. 12, 155 (1989).

[2] A. Meane, M.E. Mansori, Int. J. Adv. Manuf. Technol. 59, 9 (2012). 
[3] T.H. Chen, J.R. Yang, Mater. Sci. Eng. A Vol. 311, 28 (2001).

[4] İ. Ovali, M. Erdogan, Journal of Polytechnic 15, 43 (2012).

[5] E. Oktay, V. Kilicli, M. Erdogan, Gazi Univ. J. Sci. 6, 668 (2018).
[6] L. Bartosiewicz, F.A. Alberts, I. Singh, J. Mater. Eng. Perform. 4, 90 (1994).

[7] K.S. Ravishankar, K.R. Udupa, P.P. Rao, Int. J. Cast Metals Res. 23, 330 (2010).

[8] R. Martins, J. Seabra, L. Magalhães, Wear 264, 838 (2008). 